\title{
NEW GAME REGULATIONS IN THE NORTHWEST TERRITORIES, 1949
}

[Previous information on game conservation in the Canadian Arctic was published in the Polar Record, Vol. 3, No. 23, 1942, p. 490-509; No. 24, 1942, p. 567; Vol. 5, Nos. 37/38, 1949, p. 351 . The following is a short summary, prepared by the Dominion Wildlife Service, of Av Ordinance Respecting the Preservation of Gaile in the Northwest Territories. This was assented to on 21 April 1940, and came into effect on 1 July 1049 on the repeal of the Northwest Game Act. Acknowledgement is made to the Arctic Circular, Vol. 2, No. 7, 1049 , p. 89-94, from which this summary has been taken.]

The Game Ordinance, Chapter 12, as amended by Chapter 27 of the Ordinances of the Northwest Territories, is an enactment by the Commissioner and Council of the Territories. It first came into effect on 1 July 1949. Previous to that date game matters in the Territories were regulated by the Northwest Game Act, a statute of Canada, and the "Regulations Respecting Game in the Northwest Territories" issued under authority of the Act.

Iost of the important features of the Act and Regulations were embodied in the Ordinance. The regulations were rewritten, consolidated, and grouped into parts. Some new provisions were included.

The important provisions of the Ordinance and the new provisions (given in italics) may be described as follows:

\section{Part II. General Prohibitions and Restrictions}

1. No one may hunt or take game or birds' eggs or nests without a licence.

2. Prohibited is the use of:

(a) rifles of less than 0.25 calibre in big game hunting;

(b) rim-fire shells or cartridges for big game hunting;

(c) firearms of any kind for hunting beaver;

(d) autoloading weapons for hunting game;

(e) shotguns for hunting muskrats;

$(f)$ snares for hunting other than rabbits or hares.

3. Traps must not be set or left set in the close season, or for wolves between 1 April and 31 October. When traps have been lawfully set by a trapper it is an offence for another person to remove them.

4. Game and furs must not be wasted by being neglected and left to spoil.

5. It is an offence to be in possession of game taken illegally or to make an agreement with a native to take game illegally.

6. Moose meat may not be sold or offered for sale.

7. Caribou meat may be sold by the holder of a general hunting licence. It may not be sold by traders or in cans.

8. The meat of game must not be served with meals for which a charge is made.

9. Moose and caribou meat must not be fed to domestic animals and game meat must not be used for bait if fit for human consumption.

10. Aircraft may be used by hunters only for transportation to their trapping headquarters. Permission must be secured to transport game meat or furs by aircraft. Huniing game from an aircraft is prohibited. 
11. It is an offence to molest or interfere with a muskrat house or a beaver dam or beaver house.

12. Poison must not be used in hunting except by authorised scientists and game officers.

\section{Part III. Game Preserves and Sanctuaries}

1. Six game preserves, comprising some 900,000 square miles, are reserved for exclusive hunting by Indians and Eskimo.

2. More than 15,000 square miles is included in two sanctuaries where hunting game of any kind is forbidden.

3. Hunting beaver is forbidden in the Mackenzie Delta Beaver Sanctuary, an area of approximately 14,000 square miles.

\section{Part IV. Close Seasons}

1. Hunting in the close season is prohibited. Exceptions are that Indians and Eskimo may

(a) hunt male caribou in March for food;

(b) hunt caribou in August and September to get skins for clothing

and that any one may take game as needed to prevent starvation in the close season or otherwise.

2. The season is closed throughout the year on a number of animals and birds, including musk-ox and buffalo.

3. Hunting females or young under one year of age of moose, mountain sheep and mountain goats is prohibited.

4. The bag limit on moose is one male per year.

\section{Parts V and VI. Licences and Certificates}

1. Some fifteen licences and certificates are issued under the Ordinance. In general, applications are taken and licences issued by local game officers. Exceptions are trading post or outpost licences, scientific licences, and licences to export live animals which are issued at Ottawa. Certificates of registration, fur-farm licences, and licences to take fur-bearers, are issued by the office of the District Administrator, Fort Smith when they apply to Mackenzie District, otherwise by the Ottawa office.

2. Indians and Eskimo are required to take out general hunting licences in order to hunt. Formerly they were not so required. No fee is charged them.

3. A general hunting licence is issued to a white person only in the case of

(a) a person who held a hunting and trapping licence on 3 May 1938, and has continued to reside in the Territories; or

(b) a child of a resident who continues to reside in the Territories and is dependent on hunting for a livelihood.

The fee charged is $\$ 5.00$ (it was formerly $\$ 2.00$ ).

4. Caribou licences may be issued to resident heads of families, representalices of missions, and government employees, but only for the purpose of obtaining meat for their own use.

5. Game bird licences are obtainable by all. 


\section{PART VII. Registration in Mackenzie District}

1. Certificates of registration may be issued to holders of general hunting licences and give them exclusive trapping rights in their trapping areas. A certificate covers a period of five years.

2. Trapping areas may be registered by groups or bands of natives if they so desire. The certificate is issued in the name of the chief or leader.

3. Hunters may hunt big game over registered areas, and registrants may go off their areas to hunt big game. The latter must not trap off their areas except by special permission.

t. Registration certificates are free to Indians and Eskimo. For others the fee is $\$ 10$ per person.

5. The registrant must make proper use of his area or lose his certificate. Improvements made by him on the area may be sold or disposed of.

\section{PART VIII. Beaver and Marten Licences}

1. The season is closed throughout the year for beaver and marten hunting except in defined areas in Mackenzie District where hunting by general hunting licence holders is permitted under special free beaver and marten licences.

2. In registered areas the limit is one beaver for each colony established on the area over a minimum of three. For unregistered hunters the limit is ten. The limit is five marten south of the $63^{\circ} \mathrm{N}$. parallel, ten marten north of it. In the basin of the Anderson River limits of twenty beaver and twenty-five marten are provided.

3. When a hunter obtains a beaver or marten licence he is given a number of seals to.correspond with the number of beaver or marten allozced on the licence. He must attach one seal to each beaver or marten pelt. Possession of unsealed pelts is an offence.

\section{ParT IX. Trading and Trafficking in Game}

1. Anyone wishing to trade and traffic in game in the Territories, except government employees, who are forbidden to do so, must first obtain a licence to establish a trading post or outpost. In order to carry on the business he must obtain an annual trading and trafficking licence.

2. Residents may purchase skins for clothing and temporary residents and visitors are allowed to buy up to $\$ 200$ worth of fur without a licence.

3. Fees for trading and trafficking licences are based on status of owner or manager. Indians, Eskimo, and religious organizations accepting furs as contribution to their maintenance are not charged a fee. For others, resident fee is \$10, non-resident Canadian $\$ 150$, and alien $\$ 300$.

4. Each trader must give his customer a record of any sale or purchase, must keep proper accounts, and must display his prices on his merchandise. Provision is made for inspection of the books and records of traders by authorised officers.

\section{Part X. Fur-farms and Live Game}

1. No one may establish a fur-farm or take or export wild live fur-bearing animals without a licence. 
2. A fur-farm licensee is required to keep proper records, make annual returns, and submit to inspection of his farm.

3. The number of fur-bearers which may be taken or exported is limited, and regulations are provided for trapping and shipping the animals.

\section{PART XI. Powers of the Commissioner}

For convenience and clarity the various powers of the Commissioner of the Northwest Territories under the Ordinance are grouped together in one part and include new provisions (subsections $(g),(h),(i)$ and $(j)$ ).

\section{PART XII. Administration and Enforcement}

1. Game Officers are appointed under the Ordinance, or they are members of the R.C.MI. Police.

2. Disputes between trappers may be settled by game officers. Appeal is allowed to Justices of the Peace.

3. Provision is made for search and seizure in case of suspected infractions and for disposal of seized articles after conviction is obtained. Game officers may suspend licences for suspected infractions. They may arrest offenders without a warrant.

4. A false statement in an application or report made under the Ordinance is an offence.

5. A licence is automatically cancelled if the holder is convicted of a violation.

6. Penalties of fine and imprisonment are provided. The maximum fine is $\$ 5000$ for hunting or trading and trafficking without a licence, for illegal use or possession of poison, and for killing buffalo or musk-ox. The maximum for other offences is $\$ 500$. Minimum fines are $\$ 50$ and $\$ 5.00$ respectively.

\section{NEW ORDINANCES AFFECTING SCIENTISTS AND EXPLORERS IN THE NORTHWEST TERRITORIES, 1949}

[The following are the texts of two recent ordinances enacted by the Commissioner of the Torthwest Territories. These supersede previous regulations of June 1926 respecting scientists and explorers in the Northwest Territories, which were published in the Polar Record, Vol. 3, No. 24, 1942, p. 575-76, and of January 1945 respecting the protection and care of archaeological sites.]

Ar Ordinatice respecting Scientists and Explorers (assented to 21 April 1949)

: The Commissioner of the Northwest Territories, by and with the advice and consent of the Council of the said Territories, enacts as follows:

" 1 . This Ordinance may be cited as the Scientists and Explorers Ordinance.

"2. (i) The Commissioner may issue a licence, subject to such conditions as to duration, area or otherwise as he may prescribe, to a person to enter the Territories for scientific or exploration purposes and to carry out those purposes in the Territories.

"(ii) The Commissioner may, at any time, for any cause that to him seems sufficient, extend, renew, alter or revoke a licence issued under this section. 